Research Article

\title{
Comparative study on the degree of correction and type of complication between modified French and dome supracondylar osteotomy in a tertiary care centre of West Bengal
}

\author{
Mitra S. R. ${ }^{1}$, Ghosh S. ${ }^{2}$ \\ ${ }^{1}$ Dr. Subhasis Ranjan Mitra, Associate Professor, Department of Orthopaedic Surgery, Calcutta National Medical \\ College, ${ }^{2}$ Dr Saswata Ghosh, Assistant Professor, Department of Chest Medicine, Malda Medical College, Malda, West \\ Bengal, India.
}

Corresponding Author: Dr. Saswata Ghosh, Assistant Professor, Department of Chest Medicine, Malda Medical College, Malda. Postal Address- Krishna Residency, Phase II, Flat No.: 2A, Baroaritola, Kestopur, Kolkata. West Bengal, India. E-mail: drsaswata1969@gmail.com

\begin{abstract}
Introduction: Cubitus Varus is one of the most common deformity around the elbow. Malunited supracondylar fracture of humerus is the most common cause of the deformity in children. This study was conducted to compare the degree of correction and type of complication between modified French and dome supracondylar osteotomy. Materials and Methods: The present study is a prospective study of 61 children with Cubitus Varus treated surgically between January 2017 to May 2018. In our series of 61 cases, 31 were treated with modified French osteotomy and 30 with dome osteotomy. The patients were followed up periodically. Results: At final follow-up by Flynn's criteria for functional outcome 19 had excellent outcome, 9 had good result, 3 had fair result and none had poor result in modified French group. In dome osteotomy group 15 had excellent result, 10 had good result, 5 had fair result. There was 1 case of infection, 1 case of delayed union, 1 case of implant failure and no nerve injury. In modified French group. There were 2 cases of infection, 1 case of delayed union, 2 cases of implant failure, and 1 case of nerve injury in dome osteotomy group. Conclusion: The present study found that the degree of correction was same, but rate of complication was less in modified French treated group than in dome osteotomy group. Though lateral prominence was corrected in dome osteotomy it was associated with more complication, inadequate correction, nerve palsy, loss of motion and circulatory compromise.
\end{abstract}

Keywords- Cubitus Varus, Dome osteotomy, Modified French osteotomy

\section{Introduction}

Cubitus Varus is a common deformity in which the extended forearm is deviated towards midline of the body. It is often referred to as 'Gunstock deformity' because of the crooked nature of its healing. The most common cause of this deformity is the malunited supracondylar fracture of humerus [1].

Supracondylar fracture of humerus account for about $18 \%$ fractures in the pediatric population, occurring mainly between the age of 5 to 10 years. Many of these displaced fractures become unstable after reduction. Immobilization in right angle position will frequently allow the fragment to slip and the necessity of repeated

Manuscript Received: $20^{\text {th }}$ May 2019

Reviewed: $30^{\text {th }}$ May 2019

Author Corrected: $6^{\text {th }}$ June 2019

Accepted for Publication: $11^{\text {th }}$ June 2019 manipulations causing elbow stiffness, myositis ossificans and physical damage in which varus deformity is the most frequent problem [2-5]. The deformity not only results in loss of alignment but also has recurvatum deformation in sagittal plane and internal rotation deformity in axial plane. Lying in the plane of motion of the joint, a recurvatum deformity remodels well.

Internal rotation deformity is compensated by movements of the shoulder and correction in both cases is focused on coronal plane deformity [6]. Surgery should be done after maximum remodeling, roughly after one year.Other causes of cubitus varus include growth disturbances, medial tilt and unreduced inward rotation. There are several corrective osteotomies 


\section{Research Article}

available to correct a cubitus varus deformity with a high probability of success. Lateral close wedge French osteotomy is most commonly used but comes with its own set of complications such as lateral condylar prominence, movement limitations and unsightful scars [7-9]. Some of these complications are overcome by dome osteotomy that according to research provides stability of the correction avoids lateral condylar prominence as well as leaves more acceptable scars. However, studies comparing degree of correction and types of complications between the two is required to assess the most efficient corrective method for the population of interest.

\section{Aims and Objectives}

Our study is to analyze and compare functional outcome, complications between modified French and dome osteotomy in cubitus varus in children treated in a tertiary care centre. The specific objectives are as following:

1. To obtain and maintain correction.

2. To gain the physical and radiological long-term normal result

\section{Materials and Methods}

a) Study type: Hospital based Prospective study.

b) Sample size: Total 61 patients with Cubitus Varus were enrolled.

c) Sampling technique: Consecutive non probability technique used

d) Inclusion criteria: 1). Patients with cubitus varusdeformity 2) Age of patient between 5-15 years old. 3) Deformity present more than 12 months

e) Exclusion criteria:1)Patients younger than 5 yrs and older than 15 yrs. of age 2) Patients with deformity present for less than 12 months, 3) Patients that have been deemed anesthetically unfit 4) Patients that were lost to follow up.

f) Study procedure and place of study: The study commenced after obtaining permission from Institutional Ethical Committee and written informed consent from patients. 70 patients with cubitus varus deformity presented to our hospital between January 2017 and May 2018. Out of these, 61 patients were treated by surgical procedure (modified French and dome osteotomy), who fulfilled the criteria for the study. The present study includes cases of cubitus varus treated with corrective osteotomy (modified French and dome osteotomy) at Calcutta National Medical college \& Hospital, West Bengal. All these 61 patients were followed for a period of 6 months. During the follow-up $\mathrm{x}$-rays were taken and the patients were assessed clinically and radiologically.

Surgical technique for Modified French osteotomyPatient was positioned supine on the operating table, with the limb on a side table. Under regional anesthesia (if unsuccessful then it was converted to general anesthesia at the discretion of the anesthetist), the parts were painted and draped. High arm tourniquet was applied. Posterolateral skin incision was made. The skin and subcutaneous tissue were divided without undermining the edges.

Lateral third of triceps was reflected from its insertion. The overlying fascia and periosteum were next divided. The osteotomy site was marked after measuring the amount of correction required, $\mathrm{k}$ wires were inserted parallel to proposed osteotomy site, one proximally one distally. After checking the position of $\mathrm{k}$ wires under $\mathrm{c}$ arm, two cortical screws were inserted parallel to $\mathrm{k}$ wires. Wedge was removed using osteotome after drill holes and both the screws brought together and is secured with the help of figure of eight tension band wiring loop around screws heads. It was supplemented by two $\mathrm{k}$ wires inserted from lateral condyle passing through osteotomy site. Confirmed in c-arm. Wound was closed in layers and the arm was rested in pop back slab.

Surgical technique for dome osteotomy- Patient was positioned supine on operating table, with limb on a side table under regional anesthesia. This part was painted and draped, and high arm tourniquet was applied. Posterolateral skin incision was made.Skin and subcutaneous tissues were divided. Lateral third triceps was reflected from its insertion. The overlying fascia and periosteum were divided. Drill holes were made in a semicircular fashion from lateral to medial side. Osteotomy was performed. Two domes were aligned and slided over one another to correct the deformity and two to three $\mathrm{K}$ wires were inserted from lateral condyle to hold both the fragments. It was supplemented by screw and SS wire in figure of 8 fashion confirmed under $\mathrm{C}$ arm. Wound was closed in layers and pop back slab was applied to the arm in 90 deg elbow flexion.

Follow-up- In both the modified French and dome osteotomy groups, the patients were followed up for 6 months post operatively. 


\section{Research Article}

Post-operative care- Antibiotics were continued for next 10 days. Analgesics were given according to needs of the patient. The operated upper limb was immobilized in a long arm back slab in elbow 90-degree flexion.

Check X-rays were taken for further study. The wound was inspected at 3 or $4^{\text {th }}$ postoperative day. Suture/ Staple removal was done on $14^{\text {th }}$ postoperative day. Patients were discharged with long arm back slab in 90deg flexion. Rehabilitation of the affected arm was started after 3-4 weeks.

\section{Results and analysis}

In the dome osteotomy group the mean age was $(8.88 \pm 1.79)$ years and in the modified French osteotomy group the mean age was $(9.55 \pm 1.97)$ years [Table 1]. Overall male child was affected more than female child in study population with $65.57 \%$ affected males and $34.43 \%$ affected females in the total population including both osteotomy groups [Table 2]. With respect to the side of injury, right elbow was predominantly involved $(56.67 \%)$ in the dome osteotomy group whereas left elbow was predominantly involved (51.61\%0 in the modified French osteotomy group [Table 3].

Radiological mean union time was 6.5 wksin both the groups [Table 4]. At final follow-up by Flynn's criteria for functional outcome 19 had excellent outcome, 9 had good result,3 had fair result and none had poor result in modified French group [Table 5]. In dome osteotomy group 15 had excellent result,10 had good result,5 had fair result [Table 5].

There was one case of infection, one case of delayed union, one case of implant failure and no nerve injury in modified French group [Table 7-10]. There were two cases of infection, one case of delayed union, 2 cases of implant failure, and one case of nerve injuryin dome osteotomy group [Table 7-10]. Tests of significance shows no significant associations between any of categorical and continuous variables and type of osteotomy performed as shown by the palues below [Table 1-10].

Table-1: Descriptive statistics of osteotomy group (Dome osteotomy, Modified French osteotomy) by age.

\begin{tabular}{|l|c|c|}
\hline Group & & AGE \\
\hline \multirow{3}{*}{ Dome osteotomy } & Mean & 8.88 \\
\cline { 2 - 3 } & Median & 8.50 \\
\cline { 2 - 3 } & Std. Deviation & 1.79 \\
\hline \multirow{3}{*}{ Modified fench osteotomy } & Mean & 9.55 \\
\cline { 2 - 3 } & Median & 9.00 \\
\cline { 2 - 3 } & Std. Deviation & 1.97 \\
\hline \multirow{2}{*}{ (c) } & p Value & 0.197 \\
\cline { 2 - 3 } & Significance & Not Significant \\
\hline
\end{tabular}

Table-2: Descriptive statistics of osteotomy group stratified by sex.

\begin{tabular}{|c|c|c|c|c|c|c|}
\hline \multicolumn{2}{|c|}{} & \multicolumn{2}{|c|}{ Group } & & \\
\cline { 3 - 4 } & Dome osteotomy & Modified fench osteotomy & & $\mathrm{p}$ Value & Significance \\
\hline \multirow{2}{*}{ Sex } & Female & $12(40)$ & $9(29.03)$ & $21(34.43)$ & \multirow{2}{*}{0.367} & \multirow{2}{*}{ Not Significant } \\
\cline { 2 - 4 } & Male & $18(60)$ & $22(70.97)$ & $40(65.57)$ & & \\
\hline \multicolumn{2}{|c|}{ Total } & $30(100)$ & $31(100)$ & $61(100)$ & & \\
\hline
\end{tabular}


Research Article

Table-3: Descriptive statistics of osteotomy group stratified by side of injury.

\begin{tabular}{|c|c|c|c|c|c|c|}
\hline \multicolumn{2}{|c|}{} & \multicolumn{2}{|c|}{ Group } & & \\
\cline { 2 - 4 } \cline { 3 - 5 } & Dome osteotomy & $\begin{array}{c}\text { Modified fench } \\
\text { osteotomy }\end{array}$ & Total & $\begin{array}{c}\mathrm{p} \\
\text { Value }\end{array}$ & Significance \\
\hline \multirow{2}{*}{$\begin{array}{c}\text { Side of } \\
\text { inury }\end{array}$} & Left & $13(43.33)$ & $16(51.61)$ & $29(47.54)$ & \multirow{2}{*}{0.517} & $\begin{array}{c}\text { Not } \\
\text { Significant }\end{array}$ \\
\cline { 2 - 5 } & Right & $17(56.67)$ & $15(48.39)$ & $32(52.46)$ & & \\
\hline \multicolumn{2}{|c|}{ Total } & $30(100)$ & $31(100)$ & $61(100)$ & & \\
\hline
\end{tabular}

Table-4: Descriptive statistics of osteotomy group stratified by time to union in weeks.

\begin{tabular}{|c|c|c|}
\hline \multicolumn{2}{|l|}{ Group } & Time To Union In Weeks \\
\hline \multirow{3}{*}{ Dome osteotomy } & Mean & 6.43 \\
\hline & Median & 6.00 \\
\hline & Std. Deviation & 1.72 \\
\hline \multirow{3}{*}{ Modified fench osteotomy } & Mean & 6.48 \\
\hline & Median & 6.00 \\
\hline & Std. Deviation & 1.67 \\
\hline & p Value & 0.789 \\
\hline & Significance & Not Significant \\
\hline
\end{tabular}

Table-5: Descriptive statistics of osteotomy group stratified by functional outcome (E:Excellent,F:Fair, G:Good)

\begin{tabular}{|c|c|c|c|c|c|c|}
\hline & & \multicolumn{2}{|c|}{ Group } & \multirow[b]{2}{*}{ Total } & & \multirow[b]{2}{*}{ Significance } \\
\hline & & $\begin{array}{c}\text { Dome } \\
\text { osteotomy }\end{array}$ & $\begin{array}{l}\text { Modified fench } \\
\text { osteotomy }\end{array}$ & & $\begin{array}{c}\mathrm{p} \\
\text { Value }\end{array}$ & \\
\hline \multirow{3}{*}{$\begin{array}{l}\text { Functional } \\
\text { outcome }\end{array}$} & $\mathrm{E}$ & $15(50)$ & $19(61.29)$ & $34(55.74)$ & \multirow{3}{*}{0.589} & \multirow{3}{*}{$\begin{array}{c}\text { Not } \\
\text { significant }\end{array}$} \\
\hline & $\mathrm{F}$ & $5(16.67)$ & $3(9.68)$ & $8(13.11)$ & & \\
\hline & G & $10(33.33)$ & $9(29.03)$ & $19(31.15)$ & & \\
\hline \multicolumn{2}{|l|}{ Total } & $30(100)$ & $31(100)$ & $61(100)$ & & \\
\hline
\end{tabular}

Table-6: Descriptive statistics of osteotomy group stratified by ROM (range of motion) group.

\begin{tabular}{|c|c|c|c|c|c|c|}
\hline & & \multicolumn{2}{|r|}{ Group } & \multirow{2}{*}{ Total } & & \\
\hline & & Dome osteotomy & Modified fench osteotomy & & $P$ value & Significance \\
\hline \multirow{4}{*}{ ROM } & $0-100$ & $1(3.33)$ & $1(3.23)$ & $2(3.28)$ & \multirow{4}{*}{0.897} & \multirow{4}{*}{ Not significant } \\
\hline & $0-120$ & $12(40)$ & $14(45.16)$ & $26(42.62)$ & & \\
\hline & $0-130$ & $15(50)$ & $13(41.94)$ & $28(45.9)$ & & \\
\hline & $10-120$ & $2(6.67)$ & $3(9.68)$ & $5(8.2)$ & & \\
\hline \multicolumn{2}{|c|}{ Total } & $30(100)$ & $31(100)$ & $61(100)$ & & \\
\hline
\end{tabular}


Research Article

Table-7: Prevalence of infection in osteotomy group.

\begin{tabular}{|c|c|c|c|c|c|c|}
\hline \multicolumn{2}{|c|}{} & \multicolumn{2}{|c|}{ Group } & \multirow{2}{*}{ Total } & \\
\cline { 3 - 4 } \cline { 3 - 5 } \multicolumn{2}{|c|}{} & Dome osteotomy & Modified fench osteotomy & & P value & Significance \\
\hline \multirow{2}{*}{ Infection } & No & $28(93.33)$ & $30(96.77)$ & $58(95.08)$ & \multirow{2}{*}{0.612} & \multirow{2}{*}{ Not significant } \\
\cline { 2 - 5 } & Yes & $2(6.67)$ & $1(3.23)$ & $3(4.92)$ & & \\
\hline \multicolumn{2}{|c|}{ Total } & $30(100)$ & $31(100)$ & $61(100)$ & & \\
\hline
\end{tabular}

Table-8: Descriptive statistics of osteotomy group stratified by presence of nerve injury.

\begin{tabular}{|c|c|c|c|c|c|c|}
\hline & \multicolumn{2}{|c|}{ Group } & \multirow[b]{2}{*}{ Total } & & \\
\hline & & Dome osteotomy & $\begin{array}{l}\text { Modified fench } \\
\text { osteotomy }\end{array}$ & & $\mathrm{P}$ value & Significance \\
\hline \multirow{2}{*}{ Nerve injury } & No & $29(96.67)$ & $31(100)$ & $60(98.36)$ & \multirow{2}{*}{0.492} & \multirow{2}{*}{$\begin{array}{c}\text { Not } \\
\text { significant }\end{array}$} \\
\hline & Yes & $1(3.33)$ & $0(0)$ & $1(1.64)$ & & \\
\hline \multicolumn{2}{|c|}{ Total } & $30(100)$ & $31(100)$ & $61(100)$ & & \\
\hline
\end{tabular}

Table-9: Descriptive statistics of osteotomy group stratified by presence of delayed union

\begin{tabular}{|c|c|c|c|c|c|c|}
\hline \multirow{2}{*}{} & \multicolumn{2}{|c|}{ Group } & & \multirow{2}{*}{ Total } & P value & Significance \\
\cline { 3 - 4 } \cline { 3 - 4 } & $\begin{array}{c}\text { Dome } \\
\text { osteotomy }\end{array}$ & $\begin{array}{c}\text { Modified fench } \\
\text { osteotomy }\end{array}$ & $30(96.77)$ & $59(96.72)$ & \multirow{2}{*}{0.981} & $\begin{array}{c}\text { Not } \\
\text { significant }\end{array}$ \\
\hline \multirow{2}{*}{ Delayed union } & No & $29(96.67)$ & $1(3.23)$ & $2(3.28)$ & & \\
\cline { 2 - 5 } & Yes & $1(3.33)$ & $31(100)$ & $61(100)$ & & \\
\hline \multicolumn{2}{|c|}{ Total } & $30(100)$ & &
\end{tabular}

Table-10: Descriptive statistics of osteotomy group stratified by presence of implant failure

\begin{tabular}{|c|c|c|c|c|c|c|}
\hline & & \multicolumn{2}{|c|}{ Group } & \multirow[b]{2}{*}{ Total } & & \multirow[b]{2}{*}{ Significance } \\
\hline & & Dome osteotomy & $\begin{array}{c}\text { Modified fench } \\
\text { osteotomy }\end{array}$ & & $P$ value & \\
\hline \multirow{2}{*}{ Implant failure } & No & $28(93.33)$ & $30(96.77)$ & $58(95.08)$ & \multirow{2}{*}{0.612} & \multirow{2}{*}{$\begin{array}{c}\text { Not } \\
\text { significant }\end{array}$} \\
\hline & Yes & $2(6.67)$ & $1(3.23)$ & $3(4.92)$ & & \\
\hline \multicolumn{2}{|l|}{ Total } & $30(100)$ & $31(100)$ & $61(100)$ & & \\
\hline
\end{tabular}

Table-11: Descriptive statistics of osteotomy group stratified residual deformity

\begin{tabular}{|c|c|c|c|c|c|c|}
\hline & & \multicolumn{2}{|c|}{ Group } & \multirow[b]{2}{*}{ Total } & & \\
\hline & & Dome osteotomy & $\begin{array}{c}\text { Modified fench } \\
\text { osteotomy }\end{array}$ & & $\mathrm{p}$ Value & Significance \\
\hline \multirow{2}{*}{$\begin{array}{l}\text { Residual } \\
\text { deformity }\end{array}$} & No & $28(93.33)$ & $30(96.77)$ & $58(95.08)$ & \multirow{2}{*}{0.612} & \multirow{2}{*}{ Not significan } \\
\hline & Yes & $2(6.67)$ & $1(3.23)$ & $3(4.92)$ & & \\
\hline \multicolumn{2}{|l|}{ Total } & $30(100)$ & $31(100)$ & $61(100)$ & & \\
\hline
\end{tabular}

Table-12: Descriptive statistics of osteotomy group among those with no over correction.

\begin{tabular}{|c|c|c|c|c|c|c|}
\hline \multirow{2}{*}{\multicolumn{2}{|c|}{}} & \multicolumn{2}{|c|}{ Group } & \multirow{2}{*}{ Total } & & \\
\cline { 3 - 4 } \cline { 5 - 6 } & Dome osteotomy & Modified fench osteotomy & & P value & Significance \\
\hline Over correction & No & $30(100)$ & $31(100)$ & $61(100)$ & NA & NA \\
\hline \multicolumn{2}{|c|}{ Total } & $30(100)$ & $31(100)$ & $61(100)$ & & \\
\hline
\end{tabular}




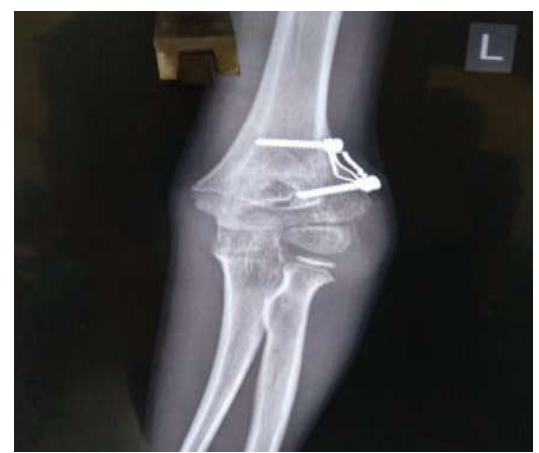

Photograph-1: Post-operative x-ray after Modified French Osteotomy

\section{Discussion}

Cubitus varus deformity after supracondylar fracture of humerus is typically the result of malunited supracondylar humerus fracture. Although there is a controversy regarding the indication for surgical correction of this deformity, previously, studies have recommended early surgical intervention once the fracture has united and there are various types of osteotomy available [10,11]. This study aims to compare between the outcomes after Modified French and Dome supracondylar osteotomy.

In this study the mean age of the patients in modified French group is $9.5 y$ rs and the Dome osteotomy group is 8.88 yrs., the $\mathrm{p}$ value came out to be 0.197 and is not significant. Due to peculiarity of this supracondylar region at around 5-7 yrs., fracture is more common. In our study males were predominant. The $\mathrm{p}$ value came out to be 0.375 which is statistically not significant. The mode of injury was fall in an outstretched hand during playing. In our study right elbow was slightly higher than left, $\mathrm{p}$ value was 0.517 which is statistically not significant.

Dominance of the hand was not taken into account. No associated injury was found in any of the groups. Functional outcome was measured as excellent, good, fair according to Flynn's criteria [12]. In Dome osteotomy group 15 had excellent outcome,10 had good and 5 had fair outcome. In Modified French group 19 had excellent outcome, 9 had good and 3 had fair outcome. p value was 0.589 and was statistically not significant.

The range of motion (ROM) was taken into account where most of the patients had a good from 0 to 130 . P value obtained was 0.897 and was statistically not significant. Presence of infection was compared among the two groups. After all aseptic measures only 2

\section{Research Article}

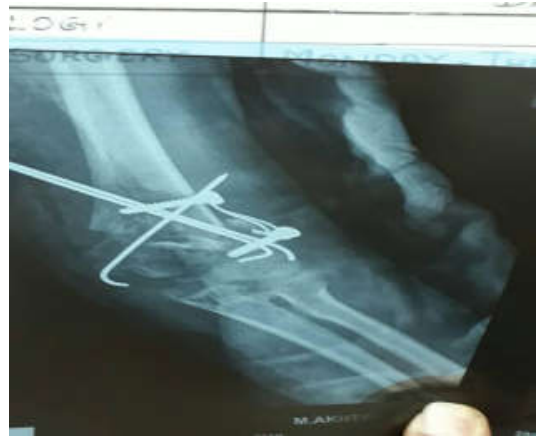

Photograph 2: Post-operative x-ray after K-wire fixation

patients in Dome group and 1 patient in the modified French group had infection. P value obtained was 0.612 . It was statistically not significant. They were treated with debridement and antibiotics. 2 patients in Dome osteotomy group and 1 patient in Modified French group had residual deformity. $P$ value was not significant and was 0.612. Proper counseling and physiotherapywere performed.

Only 1 patient in Dome osteotomy group and none in Modified French group had nerve injury. $P$ value is 0.492 and statistically not significant. Mean union time in Modified French group is 6.48 weeks and in dome osteotomy group is 6.43 weeks. One patient in each group had delayed union past 9 weeks. P value was 0.981 which is not significant.There were 2 cases of implant failure in Dome osteotomy group and 1 patient in Modified French group. P value was 0.612 and was statistically not significant.

Previous studies have proved the French's method to be safe and satisfactory. For example, results of a corrective osteotomy performed over a ten-year period on 32 patients at the Royal Alexandria Hospital for Children in Sydney proved the French's method to be safe [7]. A prospective study of Cubitus Varus deformity where 10 cases were treated with French osteotomy, all patients reported having normal range of motion of the affected elbow with no infections, hypertrophic scars or non-unions reported. In this case as well, modified French method proved safe and satisfactory [6].

On the other hand, studies involving closed dome osteotomy procedure also proved safe and effectivefor the correction except for minor complications. One of the advantages of this type of osteotomy is that it leaves a cosmetically better scar and no lateral prominence of elbow [1]. There was another comparative randomized study to compare the two different surgical techniques 


\section{Research Article}

for the correction of posttraumatic cubitus varus that found the correction to be significantly greater with the dome osteotomy group $(\mathrm{p}<0.01)$ compared to the French osteotomy group [13].

Compared to other studies, our study finds no significant difference in between the two osteotomies with respect to radiological union time and functional outcome, however from the results, modified French osteotomy is deemed an easier and safer procedure based on a comparison between the number of residual deformities, nerve injuries and implant failures.

Strength- The strength of this study lies in the fact that the results are comparable to other standard studies regarding osteotomies for treatment of cubitus varus deformity. The study adds to the evidence-based research among children aged between 5-15 years old with cubitus varus deformity. It also deems modified French osteotomy as an easier and safer procedure compared to dome osteotomy in this study population. The comparable results can be attributed to thorough pre-operative planning and meticulous intraoperative procedures.

Limitations- This study has some limitations with respect to a small number of patients were included in the study. Therefore, there was loss of power due to a smaller sample size. Also, long term follow-up could not be done to evaluate complications.

\section{Conclusion}

The present study depicts that Modified French and Dome supracondylar osteotomies showed no significant difference in radiological union time and functional outcome at final follow up. The complications arising from the procedure were within acceptable limits. Modified French osteotomy is an easier and safer procedure, but lateral prominence is less in Dome osteotomy. There was no statistical significance in any outcomes and outcome in both the groups were acceptable.

\section{Contribution by Authors}

1) Dr Subhasis Ranjan Mitra- Concept designing, conducting the study and doing the operative procedures.

2) Dr Saswata Ghosh- Conducting the study and writing the manuscript.

Conflict of interest: None declared. Funding: Nil, Permission from IRB: Yes
Summary- During the period between January 2017 \& May 2018, 31 patients were treated with Modified French and 30 patients with Dome osteotomy in Calcutta National Medical College \& Hospital, Kolkata, West Bengal. Of the 61 cases treated in this manner all were available for follow up. There was 2 cases of infection and 1 case of nerve injury in dome osteotomy group, whereas 1 infection and no nerve injury in Modified French group.

In the dome osteotomy group: At final follow up the Flynn's criteria for functional outcome 15 had excellent outcome, 10 had good and 5 had fair outcome.

In the Modified French group at final follow up: 19 had excellent outcome, 9 had good and 3 had fair outcome.

The results of our study are comparable with standard studies regarding osteotomies for treatment of cubitus varus deformity.

\section{References}

1. Verka PS, Kejariwal U, Singh B. Management of Cubitus Varus Deformity in Children by Closed Dome Osteotomy. J Clin Diagn Res. 2017;11(3):RC08-RC12. doi: 10.7860/JCDR/2017/24345.9551. Epub 2017

2. Voss FR, Kasser JR, Trepman E, Simmons JE, Hall JE. Uniplanar supracondylar humeral osteotomy with preset Kirschner wires for posttraumatic cubitus varus. Journal of pediatric orthopedics. 1994;14(4):471-8.

3. Oppenheim WL, Clader TJ, Smith C, Bayer M. Supracondylar humeral osteotomy for traumatic childhood cubitus varus deformity. Clin OrthopRelat Res. 1984;(188):34-9.

4. King D, Secor C. Bow elbow (cubitus varus). J Bone Joint Surg Am. 1951;33-A(3):572-6.

5. Roach JW. Corrective osteotomy for cubitus varus deformity. Journal of pediatric orthopedics. 1994;14 (4): 487-91.

6. Dudhekar U. Prospective Study of Cubitus Varus Deformity, Its Etiopathology, Clinical Study and Treatment. Vol5.;2016. DOI:10.18203/2320-6012. ijrms 20164549

7. Bellemore MC, Barrett IR, Middleton RW, Scougall JS, Whiteway DW. Supracondylar osteotomy of the humerus for correction of cubitus varus. J Bone Joint Surg Br. 1984 ;66(4):566-72. 


\section{Research Article}

8. Levine MJ, Horn BD, Pizzutillo PD. Treatment of posttraumatic cubitus varus in the pediatric population with humeral osteotomy and external fixation. J Pediatr Orthop. 1996;16(5):597-601.

9. Usui M, Ishii S, Miyano S, Narita H, Kura H. Threedimensional corrective osteotomy for treatment of cubitus varus after supracondylar fracture of the humerus in children. J Shoulder Elbow Surg. 19954 (1 Pt 1):17-22.

10. Song HR, Cho SH, Jeong ST, Park YJ, Koo KH. Supracondylar osteotomy with Ilizarov fixation for elbow deformities in adults. J Bone Joint Surg Br. 1997;79(5):748-52.
11. Morrey BF. Post-traumatic contracture of the elbow. Operative treatment, including distraction arthroplasty. J Bone Joint Surg Am. 1990;72(4):601-18.

12. Khan RD, Yousaf MN, Rehman MZ, Fareed MI, Yasin A. Outcome of open reduction internal fixation with cross K-wires for supracondylar fracture of humerus in terms of Flynn's criteria in children. JPMA. 2015 Nov 1;65.

13. Kumar K, Sharma VK, Sharma R, Maffulli N. Correction of cubitus varus by French or dome osteotomy:a comparative study. J Trauma. 2000 Oct; 49 (4):717-21.DOI:10.1097/00005373-200010000-00021.

\section{How to cite this article?}

Mitra S. R, Ghosh S. Comparative study on the degree of correction and type of complication between modified French and dome supracondylar osteotomy in a tertiary care centre of West Bengal. Surgical Update: Int J surg Orthopedics. 2019;5 (3):138-145. doi:10.17511/ijoso.2019.103.03. 